\title{
A weird DNA band in PCR and its cause
}

\author{
Chang Shenghe ${ }^{1,2}$, Sun Wei ${ }^{1,2}$, Zhou Zhaoxi ${ }^{1,2}$, Li Jingyang ${ }^{1,2}$, Dai Minjie ${ }^{1,2}$ and Shu Haiyan ${ }^{1,2^{*}}$
}

*Correspondence: shuhy@zzu.edu.cn

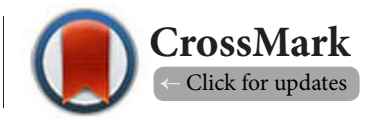

${ }^{1}$ Haikou experimental station, Chinese Academy of Tropical Agricultural Sciences, Haikou, China.

${ }^{2}$ The key lab of Hainan banana genetics and breeding, Haikou, China.

\begin{abstract}
Purpose: Polymerase chain reaction (PCR) has been widely used in biological experiments. Sometimes, the PCR product can not go out of the sample groove in agarose gel. Such DNA band was called ghost band in many labs. However, how ghost band formed and how to prevent ghost band, no paper had been reported. The purpose of this paper was to study how ghost band formed and how to prevent ghost band in PCR experiments.
\end{abstract}

Methods: For verifying the infer that the ghost was from the target DNA sequence linked each other, primers containing restriction enzyme sites were designed. The ghost band was digested with the responding enzyme. For verifying the infer that ghost band was due to that the primers bind with the unspecific target DNA sequence, both common PCR procedure and gradient PCR procedure were used to compare the effects of annealing temperature on ghost band.

Conclusions: We found that two factors caused ghost band. The first was that the template used in the PCR was the purified PCR product itself. The second was that the annealing temperature used in the PCR procedure was near to but lower than the ideal annealing temperature. If one of these two factors was not provided, ghost band can be avoided.

Keywords: Ghost band, polymerase chain reaction (PCR), agarose gel

\section{Introduction}

Polymerase chain reaction (PCR) technique had been widely used in most of the the fields of biology research since its invention [1-10]. PCR can amplify minute amounts of target DNA within a few hours [11,12]. However, if the template was lower than a certain level, the technique will be fraught with difficulties [13]. Traditional methods used to resolve this problem was performing nested PCR. However, traditional nested $P C R$ required two pair of primers. The length of the product amplified using the inner primers is shorter than that of product amplified using the outer primers. If the target sequence is short and the sequence suitable for designing primers is scarce, it will be difficult for performing nested PCR. If nested PCR can be performed only using one pair of primers, this problem will be resolved and will be more convenient for nested PCR. Recently, we did a nested PCR using one pair of primers. But we found a weird DNA band shown in agarose gel after the PCR product was electrophoresed. The DNA band can not go out of the sample groove. Sometimes, the DNA band only appear near the sample groove. There was no band in the predicted position. The cause of this phenomenon was studied in this paper. Results gotten in this paper may be used widely in PCR.

\section{Materials and methods}

The plasmid $\mathrm{p}$ (merT-merP-merB1-merB2-ppk) and pp(merTmerP-merB1-merB2-pcs1) were stored in our lab [14]. The gene ppk (GenBank accession number: D14445.1) in the plasmid $\mathrm{pp}$ (merT-merP-merB1-merB2-ppk) was from the the polyphosphate kinase (ppk) gene isolated from Enterobacter aerogenes [15]. The gene NtPCS1 (GenBank: AY235426.1) in the plasmid $\mathrm{p}$ (merT-merP-merB1-merB2-pcs1) was from the phytochelatin gene isolated from tobacco [16], 2005). The primers used for amplifying pcs 1 sequence were NPCSF (5'-TCACCGGAATTCATGGCGATGGCGGGTTT- $3^{\prime}$ ) and NPCSR (5'-ATACCGGAATTCGCAAAGCTAGAAGGGAG-3'). The primers used for amplifying ppk gene were PPK03F (5'-TCACCGGAATTCATGGGTCAGGAAAAGT- 
Shenghe et al. Journal of Plant Science \& Molecular Breeding 2016,

http://www.hoajonline.com/journals/pdf/2050-2389-5-2.pdf

TATATATCGAGAAAG-3') and PPK03R (5'-ATACCGGAATTCTTAATCGGGTTGCTCGAGTGATTTGATATAG-3'). The PCR reaction mixture contained 2xPfu MasterMix (Beijing ComWin Biotech Co., Ltd, Cat: CW0686A), PPK03F 1 pmol, PPK03R 1 pmol, $\mathrm{H}_{2} \mathrm{O}$ $22 \mu \mathrm{l}$, DNA $2.5 \mathrm{ng}$. The common PCR procedure used for amplifying ppk gene was $94^{\circ} \mathrm{C} 5 \mathrm{~min} ;\left(94^{\circ} \mathrm{C} 30 \mathrm{sec}, 57^{\circ} \mathrm{C} 30 \mathrm{sec}\right.$, $72^{\circ} \mathrm{C} 2 \mathrm{~min}$ ), 40 cycles; $72^{\circ} \mathrm{C} 7 \mathrm{~min}$. The gradient PCR used for amplifying ppk gene was $94^{\circ} \mathrm{C} 5 \mathrm{~min} ;\left(94^{\circ} \mathrm{C} 30 \mathrm{sec}, 60^{\circ} \mathrm{C}-40^{\circ} \mathrm{C}\right.$ $\left.30 \mathrm{sec}, 72^{\circ} \mathrm{C} 2 \mathrm{~min}\right), 40$ cycles; $72^{\circ} \mathrm{C} 7 \mathrm{~min}$. The PCR procedure used for amplifying NtPCS was $94^{\circ} \mathrm{C} 5 \mathrm{~min} ;\left(94^{\circ} \mathrm{C} 30 \mathrm{sec}\right.$, $\left.55.4^{\circ} \mathrm{C} 30 \mathrm{sec}, 72^{\circ} \mathrm{C} 1.5 \mathrm{~min}\right), 40$ cycles; $72^{\circ} \mathrm{C} 7 \mathrm{~min}$. The PCR reaction mixture contained $2 \times$ Pfu MasterMix (Beijing ComWin Biotech Co., Ltd, Cat: CW0686A), NtPCSF 1 pmol, NtPCSR $1 \mathrm{pmol}, \mathrm{H}_{2} \mathrm{O} 22 \mu \mathrm{l}$, DNA $2.5 \mathrm{ng}$. The plasmid DNA Miniprep Kit (Cat No: RTP2102) was bought from Real-Times Biotechnology Company Limited (Beijing, China). PCR products were recovered from 1.0\% agarose gel using Gel extraction Kit (Beijing ComWin Biotech Co., Ltd, China). PCR was performed using the purified products as template. The primers and PCR conditions were as described above. Amplified products were electrophoresed and visualized in a 1.0\% agarose gel stained with GoldView nucleic acid dye (Shanghai Juncheng, China). $5 \mu \mathrm{L}$ of each of 3 replicate PCR products were combines and mixed to form a pooled sample. Five microliters of this pooled sample was injected into the gel groove. The electrophorese was performed in TBE buffer. The DNA band was visualized using a G:BOX Gel imager (SynGENE, Britain).

\section{Results and discussion}

Recently, we performed a PCR using a plasmid $p$ (merT merP -merB1-merB2-ppk) [14] as template (Figure 1). The expected DNA band appeared in the agarose gel (Figure 2). After being purified from agarose gel (Figure 3), most of the purified sample was used for another experiments. At the same time, most of the plasmid sample had also been used up. To get more experiments sample, PCR was performed using the purified DNA as template. When the PCR products were electrophoresed in $0.8 \%$ agarose gel, we were horrified by the experiment result. The ghost band appeared (Figure 4). Although the DNA ladder had been shown normally in the agarose gel, the PCR products remained in the gel groove (Figure 4). To identify whether ghost band was from the problem of electrophoresis buffer, electrophoresis was performed once again using fresh TAE buffer. Result showed that the DNA band still kept in gel groove. The DNA ladder can be separated normally in the agarose gel, demonstrating that the agarose gel had been prepared well. To exclude the accidents in the PCR procedure, PCR was performed once again using the plasmid as template. Results showed that the DNA band appeared in the expected position in the agarose gel (Figure 5).

We surmised that the reason might be that the template was the purified DNA sample. The purified DNA was the PCR product itself. Ghost band might have very large molecular weight. Its molecular weight is so large that it can not go out

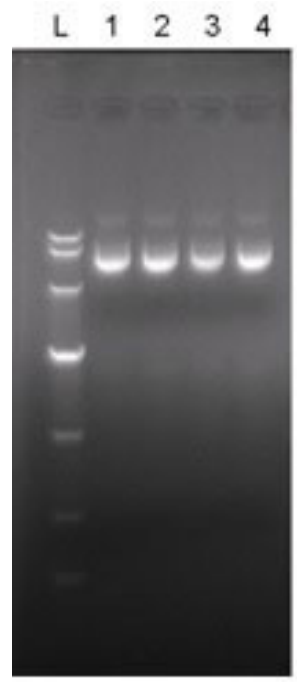

Figure 1. The plasmid of $\mathrm{p}$ (merT-merP-merB1-merB2ppk). L was the DNA ladder(DM10000, Beijing ComWin Biotech Co., Ltd, Cat: CW0634A). The molecular weight of the DNA band in DNA ladder was $10 \mathrm{~kb}, 7 \mathrm{~kb}, 4 \mathrm{~kb}, 2 \mathrm{~kb}$, $1 \mathrm{~kb}, 500 \mathrm{bp}$, and $250 \mathrm{bp}$ respectively. 1-4 referred to the plasmid pp(merT-merP-merB1-merB2-ppk) (Chang et al., 2015).

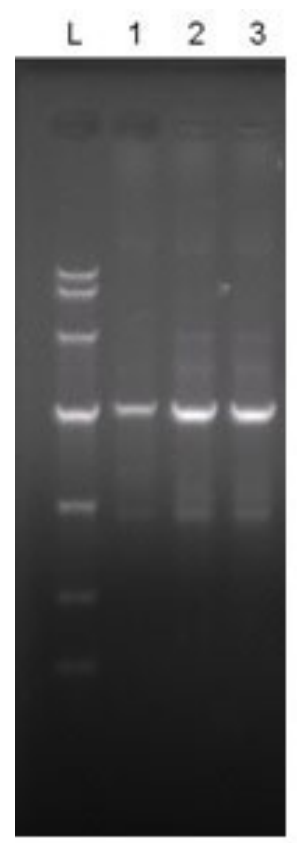

Figure 2. PCR results using the plasmid p(merTmerP-merB1-merB2-ppk) as template. $\mathrm{L}$ was the DNA ladder(DM10000, Beijing ComWin Biotech Co., Ltd, Cat: CW0634A). The molecular weight of the DNA band in DNA ladder was $10 \mathrm{~kb}, 7 \mathrm{~kb}, 4 \mathrm{~kb}, 2 \mathrm{~kb}, 1 \mathrm{~kb}, 500 \mathrm{bp}$, and 250 bp respectively. 1-3 referred to the ppk gene.

of the sample groove. There was no EcoR I enzyme digestion site in the gene sequence. But when primers were designed, 


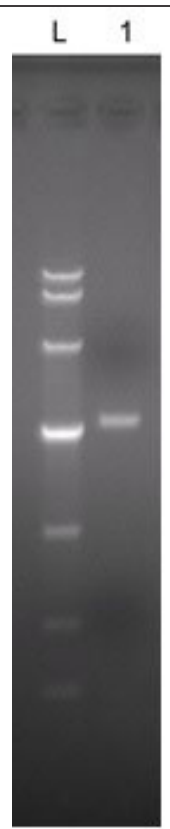

Figure 3. The PCR product was purified from the agarose gel. L was the DNA ladder(DM10000, Beijing ComWin Biotech Co., Ltd, Cat: CW0634A). The molecular weight of the DNA band in DNA ladder was $10 \mathrm{~kb}, 7 \mathrm{~kb}, 4 \mathrm{~kb}, 2 \mathrm{~kb}, 1 \mathrm{~kb}, 500 \mathrm{bp}$, and 250 bp respectively. 1 referred to the ppk gene.

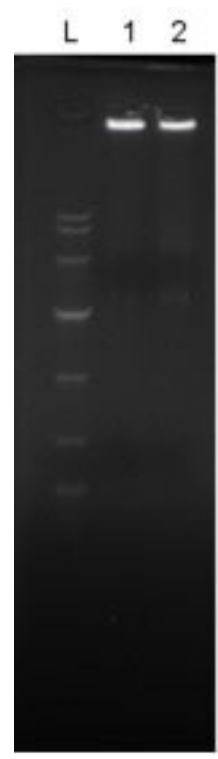

Figure 4. The ghost band. L was the DNA ladder(DM10000, Beijing ComWin Biotech Co., Ltd, Cat: CW0634A). The molecular weight of the DNA band in DNA ladder was $10 \mathrm{~kb}, 7 \mathrm{~kb}, 4 \mathrm{~kb}, 2 \mathrm{~kb}, 1 \mathrm{~kb}, 500 \mathrm{bp}$, and 250 bp respectively. 1-2 referred to the ghost band.

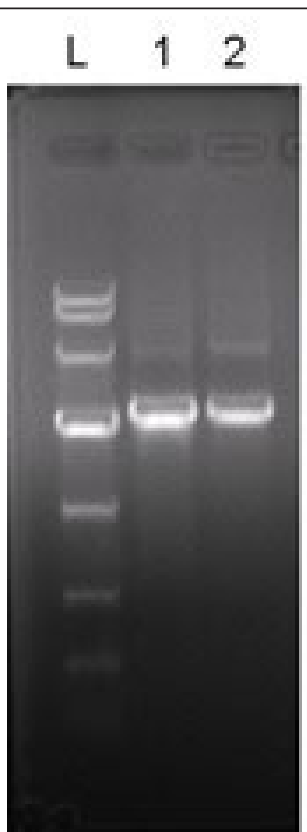

Figure 5. PCR once again using the plasmid $\mathrm{p}$ (merT-merP-merB1-merB2-ppk) as template. L was the DNA ladder(DM10000, Beijing ComWin Biotech Co., Ltd, Cat: CW0634A). The molecular weight of the DNA band in DNA ladder was $10 \mathrm{~kb}, 7 \mathrm{~kb}, 4 \mathrm{~kb}, 2$ $\mathrm{kb}, 1 \mathrm{~kb}, 500 \mathrm{bp}$, and $250 \mathrm{bp}$ respectively. 1-2 referred to the ppk gene.

an EcoR I sequence was put in each primer. Therefore, if the ghost band was from that it has too large molecular weight, the PCR product should be digested into smaller DNA band by EcoR I. Furthermore, since there was an EcoR I site at each end of the gene sequence, the molecular weight of the digested products should be similar with that of the gene. Finally, results showed that the digested products appeared in the expected position in the agarose gel (Figure 6). Its molecular weight was similar with that of the DNA band which was from the PCR using the plasmid as template (Figure 6). Therefore, ghost band was from that the PCR's template was the PCR product itself.

We proposed a possible mechanism underlying these phenotype. Under normal condition, the DNA double-strand was denatured and the single-strand formed. The primer attached to the specific region of the DNA single-strand and extend. And then, the PCR product formed (Figure 7A). However, if the template was the PCR product itself, when the DNA doublestrand band was denatured, the single-strand band has high chance to locate at the end of the other single-strand band. After the primer was annealed and extend to the end of the first single-strand band, the synthesized DNA single-strand band had high chance to continue extending using the second single-strand band as template (Figure 7B). Similarly, after the primer was extended to the end of the second single-strand 


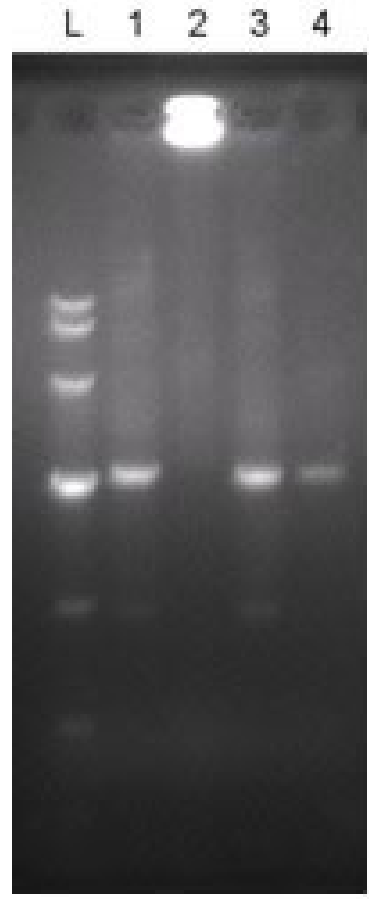

Figure 6. The ghost band and the PCR result. L was the DNA ladder (DM10000, Beijing ComWin Biotech Co., Ltd, Cat: CW0634A). The molecular weight of the DNA band in DNA ladder was $10 \mathrm{~kb}, 7 \mathrm{~kb}, 4 \mathrm{~kb}$, $2 \mathrm{~kb}, 1 \mathrm{~kb}, 500 \mathrm{bp}$, and $250 \mathrm{bp}$ respectively. 1 was the PCR result using the plasmid $\mathrm{p}$ (merT-merP-merB1merB2-ppk) as template. 2 was the ghost band. 3 was the PCR once again using the $\mathrm{p}$ (merT-merP-merB1merB2-ppk) as remplate. 4 was the ghost band was digested with the enzyme EcoR I.

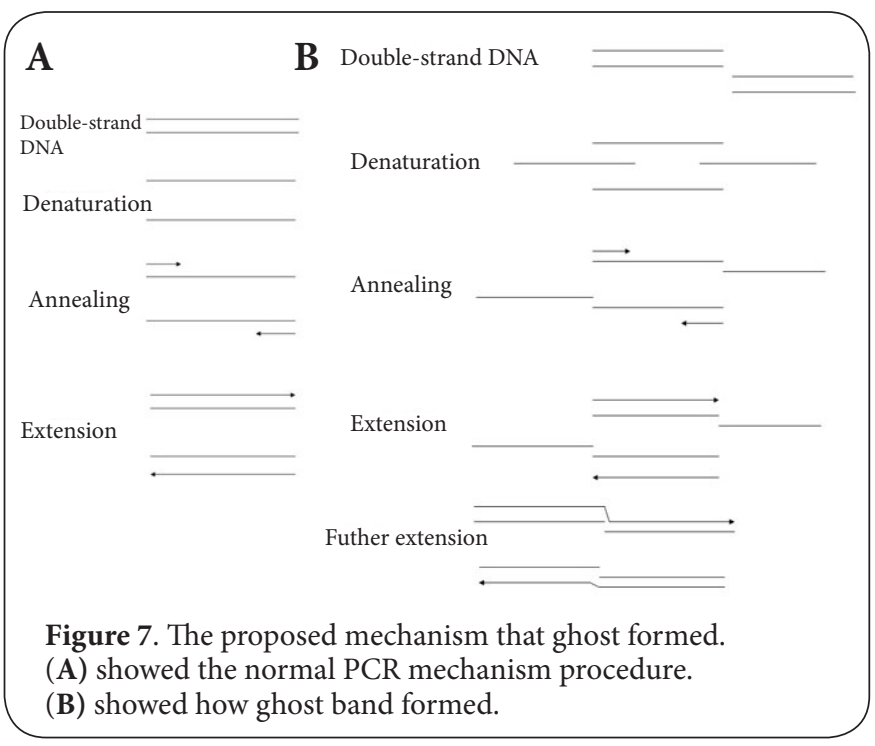

band, it had high chance to go on extending using the third single-strand band as template (Figure 7B). Finally, the resulting PCR product had large molecular weight. When the PCR product was electrophoresed in agarose gel, it can not run out of the sample groove (Figure 4). Therefore, for avoiding ghost band, the PCR product itself should not be used for further amplification.

To exclude the accidental factors, another gene NtPCS1 (GenBank: AY235426.1) was amplified using another plasmid p(merT-merP-merB1-merB2-pcs1) [14] as template. Results showed that the PCR product was normal. The PCR product was purified from agarose gel for further PCR. However, after PCR was performed using the purified PCR product as template, the DNA band appeared at the normal position (Figure 8). The ghost band did not appear. This demonstrated that using the purified PCR product as template was not the only reason which caused ghost band. The annealing temperature used in the PCR procedure might also play roles in the ghost band event. When PCR was performed, if the annealing temperature was too low, the primers will bind with the unspecific target and no DNA band would appear in the agarose gel. If the annealing temperature was near to but lower than the ideal annealing temperature, most of the primers will band with the specific target DNA sequence. But there were some primers bind with the unspecific target. On this condition, there will be some unspecific DNA bands appearing in the agarose gel. Under such conditions, the ghost band might form. If the annealing temperature was higher than the ideal value, the primers will not be able to bind with the template and no DNA band will be shown in the agarose gel. Therefore,

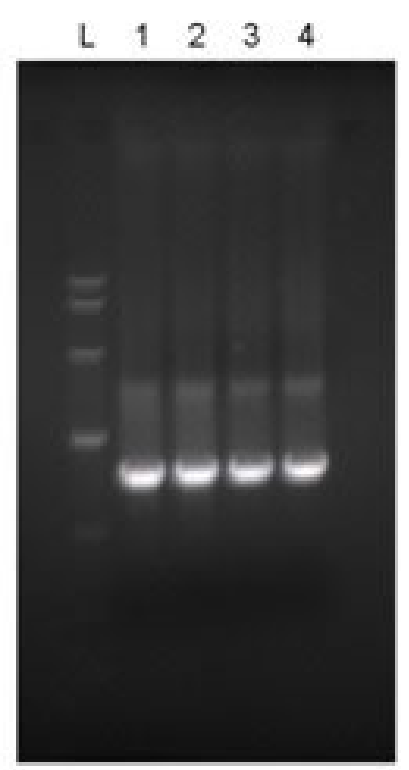

Figure 8. PCR once again using the purified NtPCS1 (Chang et al., 2015) PCR product as template. L was the DNA ladder(DM10000, Beijing ComWin Biotech Co., Ltd, Cat: CW0634A). The molecular weight of the DNA band in DNA ladder was $10 \mathrm{~kb}, 7 \mathrm{~kb}, 4 \mathrm{~kb}, 2 \mathrm{~kb}, 1 \mathrm{~kb}, 500$ bp, and 250 bp respectively. 1-4 referred to the NtPCS1 gene. 
if the annealing temperature used in the $P C R$ procedure was the ideal temperature, the ghost band might be avoided. To verify this deduction, gradient PCR was performed using the purified-ppk-PCR product as template. Results showed that the PCR product appeared at the predicted position (Figure 9). The ghost band disappeared when gradient PCR was performed.

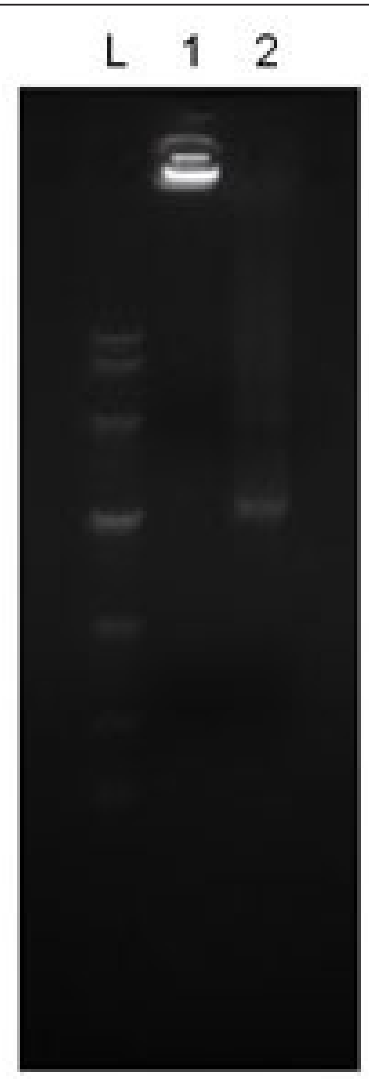

Figure 9. PCR using the purified PCR product ppk PCR product as template. L was the DNA ladder(DM10000, Beijing ComWin Biotech Co., Ltd, Cat: CW0634A). The molecular weight of the DNA band in DNA ladder was $10 \mathrm{~kb}, 7 \mathrm{~kb}, 4 \mathrm{~kb}, 2 \mathrm{~kb}, 1 \mathrm{~kb}, 500 \mathrm{bp}$, and $250 \mathrm{bp}$ respectively. 1 referred to the ppk PCR product using common PCR procedure. 2 was the ppk PCR product using gradient PCR procedure.

Therefore, the cause of ghost band was that the template used in the PCR was the purified PCR product itself and the annealing temperature was near to but lower than the ideal annealing temperature. Only that the template was the purified PCR product itself and that the annealing temperature was near to but lower than the ideal value were provided at the same time, the ghost band will form. As long as one factor of these two was not provided, the ghost band will be avoided.

\section{Competing interests}

The authors declare that they have no competing interests.

Authors' contributions
\begin{tabular}{|l|c|c|c|c|c|c|}
\hline Authors' contributions & CS & SW & ZZ & LJ & DM & SH \\
\hline Research concept and design & -- & -- & -- & -- & -- & $\checkmark$ \\
\hline Collection and/or assembly of data & $\checkmark$ & $\checkmark$ & -- & -- & -- & -- \\
\hline Data analysis and interpretation & -- & -- & $\checkmark$ & $\checkmark$ & $\checkmark$ & -- \\
\hline Writing the article & -- & -- & -- & -- & -- & $\checkmark$ \\
\hline Critical revision of the article & -- & -- & -- & -- & -- & $\checkmark$ \\
\hline Final approval of article & $\checkmark$ & $\checkmark$ & $\checkmark$ & $\checkmark$ & $\checkmark$ & $\checkmark$ \\
\hline Statistical analysis & $\checkmark$ & $\checkmark$ & -- & -- & $\checkmark$ & -- \\
\hline
\end{tabular}

Acknowledgement

This work was supported by National Science Foundation of China (No.31371696), the Key Research and Developmental Plan Item of Hainan Province (No. ZDYF2016069) and Ministry of Agriculture 948 funding of China (No.2015-Z21).

Publication history

EIC: Klaus Palme, University of Freiburg, Germany. Received: 08-Jul-2016 Final Revised: 19-Aug-2016 Accepted: 31-Aug-2016 Published: 07-Sep-2016

\section{References}

1. Saiki RK, Gelfand DH, Stoffel S, Scharf SJ, Higuchi R, Horn GT, Mullis KB and Erlich HA. Primer-directed enzymatic amplification of DNA with a thermostable DNA polymerase. Science. 1988; 239:487-91. | Article | PubMed

2. Grisedale $K$ and van Daal $A$. Linear amplification of target prior to $P C R$ for improved low template DNA results. Biotechniques. 2014; 56:145-7. | Article | PubMed

3. YukI SA, Kaiser P, Kim P, Li P and Wong JK. Advantages of using the QIAshredder instead of restriction digestion to prepare DNA for droplet digital PCR. Biotechniques. 2014; 56:194-6. | Article | PubMed Abstract | PubMed FullText

4. Zhang Y, Li X, Zou R, Xue Y, Lou X and He M. Bovine thrombin enhances the efficiency and specificity of polymerase chain reaction. Biotechniques. 2014; 57:289-94. I Article I PubMed

5. Benschop CC, van der Beek CP, Meiland HC, van Gorp AG, Westen AA and Sijen T. Low template STR typing: effect of replicate number and consensus method on genotyping reliability and DNA database search results. Forensic Sci Int Genet. 2011; 5:316-28. | Article | PubMed

6. Caragine T, Mikulasovich R, Tamariz J, Bajda E, Sebestyen J, Baum H and Prinz M. Validation of testing and interpretation protocols for low template DNA samples using AmpFISTR Identifiler. Croat Med J. 2009; 50:250-67. | Article | PubMed Abstract | PubMed FullText

7. Akbari M, Hansen MD, Halgunset J, Skorpen F and Krokan HE. Low copy number DNA template can render polymerase chain reaction error prone in a sequence-dependent manner. J Mol Diagn. 2005; 7:36-9. Article I PubMed Abstract | PubMed FullText

8. Saba Shirvan A and Mardani K. Molecular detection of infectious bronchitis and Newcastle disease viruses in broiler chickens with respiratory signs using Duplex RT-PCR. Vet Res Forum. 2014; 5:319-23. | PubMed Abstract | PubMed FullText

9. Milbury CA, Li J and Makrigiorgos GM. PCR-based methods for the enrichment of minority alleles and mutations. Clin Chem. 2009; 55:63240. | Article | PubMed Abstract | PubMed FullText

10. Annoscia G, Latrofa MS, Campbell BE, Giannelli A, Ramos RA, DantasTorres F, Brianti E and Otranto D. Simultaneous detection of the feline lung worms Troglostrongylus brevior and Aelurostrongylus abstrusus by anewly developed duplex-PCR. Veterinary Parasitology. 2014; 199:172178. | Article | PubMed

11. Louie $M$, Louie $L$ and Simor AE. The role of DNA amplification technology in the diagnosis of infectious diseases. CMAJ. 2000; 163:301-9. | Article | PubMed Abstract | PubMed FullText 
Shenghe et al. Journal of Plant Science \& Molecular Breeding 2016,

http://www.hoajonline.com/journals/pdf/2050-2389-5-2.pdf

12. Goda T, Tabata M and Miyahara Y. Electrical and electrochemical monitoring of nucleic Acid amplification. Front Bioeng Biotechnol. 2015; 3:29. | Article | PubMed Abstract | PubMed FullText

13. Zhang Y, Li X, Zou R, Xue Y, Lou X and He M. Bovine thrombin enhances the efficiency and specificity of polymerase chain reaction. Biotechniques. 2014; 57:289-94. I Article I PubMed

14. Chang S, Wei F, Yang Y, Wang A, Jin Z, Li J, He Y and Shu H. Engineering tobacco to remove mercury from polluted soil. Appl Biochem Biotechnol. 2015; 175:3813-27. | Article | PubMed

15. Kato J, Yamamoto T, Yamada $\mathrm{K}$ and Ohtake $\mathrm{H}$. Cloning, sequence and characterization of the polyphosphate kinase-encoding gene (ppk) of Klebsiella aerogenes. Gene. 1993; 137:237-42. | Article | PubMed

16. Hirata K, Tsuji N and Miyamoto K. Biosynthetic regulation of phytochelatins, heavy metal-binding peptides. J Biosci Bioeng. 2005; 100:593-9. | Article | PubMed

\section{Citation:}

Shenghe C, Wei S, Zhaoxi Z, Jingyang L, Minjie D and Haiyan S. A weird DNA band in PCR and its cause. J Plant Sci Mol Breed. 2016; 5:2.

http://dx.doi.org/10.7243/2050-2389-5-2 